\title{
Hahnemann in Sibiu:
}

\section{possible influence of the ideas of Baron d'Holbach}

\author{
Silvia Waisse Priven (MD PhD) ${ }^{1}$; Gheorghe Jurj (MD DSc) ${ }^{2}$ \\ ${ }^{1}$ Centro Simão Mathias de Estudos em História da Ciência, Pontifícia Universidade \\ Católica de São Paulo, São Paulo, Brazil; \\ ${ }^{2}$ Catedra de Filosofie şi Sțiinți ale Comunicarii, Facultatea de Sțiinte Politice, Filosofie şi \\ Sțiinte ale Comunicarii, Universitatea de Vest din Timişoara, Timişoara, Romania
}

\begin{abstract}
The present paper discusses the possible influence that the 1777-79 stay in Sibiu, at Baron of Brukenthal's palace, might have had on Samuel Hahnemann's early training. In this context, an analysis of the contents of Baron of Brukenthal's Library as depicted in a catalog to which Hahnemann contributed was performed. Data suggest that Hahnemann was particularly interested in the ideas of Baron d'Holbach. The Appendix describes all the works related to Medicine and Natural Philosophy listed in the catalog.
\end{abstract}

Keywords: Homeopathy; History; Early influences of Hahnemann; Sibiu/Hermannstadt; Holbach

\section{Introduction}

The sojourn between 1777 and 1779 of Samuel Hahnemann at the palace of Baron of Brukenthal in Sibiu (Hermannstadt), Transylvania, present-day Romania, has been the subject of continuous interest to scholars. Many traditional studies on the history of Hahnemann and homeopathy sought to establish a (scientific) biography of Hahnemann as accurate as possible; to this tradition belong works presently considered classic, including T.L. Bradford's, R. Haehl's and R. Tischner's [1,2,3]. However, none of these authors consulted the Archive and Library at Brukenthal Palace currently Brukenthal Museum - the contents of which survived the turbulent events of the $19^{\text {th }}$ and $20^{\text {th }}$ centuries.

Only very recently, thanks to careful archive work, Romanian scholar, M. Ordeanu, was able to establish some positive facts concerning Hahnemann's stay in Sibiu, which until now had been the focus of intense speculation for historians and homeopaths alike. For this reason, they are worthy to be overviewed here [4].

First, the tasks Hahnemann performed at Brukenthal's palace were restricted to cataloging the Baron's coin collection. (Fig.1) Concerning the
Library catalog, it had already been made by administrative employees Henning and Johann Theodor Hermann and the Baron's nephew, Johann Michael Soterius; Hahnemann contributed only with a revision. (Fig.2)

Further, according to current legislation, Hahnemann was not allowed to practice Medicine; on the other hand, the physician in charge of the Brukenthal family's health as well as medical matters in the area was Michael Neustädter. The latter seems to have been an important influence to Hahnemann, probably intermediating his access to both the local Freemason lodge and the medical school of Erlangen university.

Speaking of Freemasonry, Hahnemann indeed was affiliated in Sibiu, yet records register this one only inaugural participation. This suggests that any later influence of Freemasonry, if any, in Hahnemann's life has to be sought for in a setting other than Sibiu's.

Ordeanu paints a colorful but unexpected picture of the relationship between the Baron and Hahnemann, ranging from complete indifference of the former to the latter to a still unclear episode that could be related to the departure of Hahnemann from Sibiu, which is very discretely 
just hinted at by Ordeanu, who preferred to focus on the meager economic retribution as the reason for Hahnemann's leave. Hahnemann received one only payment of 50 Gulden, insufficient to continue his medical studies, as can be inferred from T. Broman's study on the costs of medical education in Germany at the end of the $18^{\text {th }}$ century [5]. Hahnemann's own account must be considered with care, as his tendency to distort data in his biography has already been documented [6].

Finally, as Medicine is not her field of research, Ordeanu merely highlights some medical works listed in the catalog - currently Bibliotecii Muzeului Brukenthal (BMB) Ms 87 [7] - according to their importance to late $18^{\text {th }}$ century medicine, and states the origin of the virtually unknown ones - donations by physicians and local medical students upon graduation.

This, shortly, was the state of scholarship concerning Hahnemann's stay in Sibiu. Yet, two important questions still remained to be addressed. First, what might have been the influence of this journey on Hahnemann's medical training, if any, and eventually on the later development of Homeopathy? Second, R. Ruiz, in his doctoral work, argued that homeopathic notions and procedures on "dynamization" have strong roots in medieval Arabic Alchemy [8]. However, he was not able to establish where Hahnemann could have had access to such sources, as they were not openly available in European libraries.

Medieval Alchemy scholar A. Alfonso - Goldfarb suggested the authors, in a personal communication, that the geographical location of Transylvania, at the intersection of the Western and Oriental worlds, might have favored the presence of Arabic influences and works in local libraries.

These were, shortly, the two questions the authors of the present paper sought to answer by conducting research at Brukenthal Library. The latter was the easiest: there are absolutely neither works in Arabic nor by Arabic authors in the catalog of books extant in Hahnemann's time. On the other hand, the catalog mentions several works related to Alchemy and Hermeticism.

Although there are no sources available allowing to establish with certainty that Hahnemann actually consulted them, a previous study by one of the authors identified themes of both fields in Hahnemann's later thought [9]. On the other hand, as it is well known, many of these works mention
Arabic authors, thus, it is highly possible that Hahnemann learned of them in Sibiu.

As a commentary, we would like to add that, involuntary, more of homeopathic lore could be ascertained, concerning the possible languages Hahnemann learned in Sibiu. Hebrew has been previously discussed $[9,10]$. Concerning Chaldaic, upon ocular testimony of actual works, we could establish it is, in fact, Aramaic. (Fig.3)

The attribution of the name "Chaldaic" to Aramaic was made by Sebastian Münster, one of the most important Christian Hebraists in the $16^{\text {th }}$ century and became common ever since. Indeed, Münster's Dictionarium Chaldaicum (edition of Basileae, 1527) is listed in BMB Ms 87.

The question concerning the probable influence of Hahnemann's time in Sibiu on his later activities is not easy to establish. Ms 87 - an inventory of books existing at the Baron's Library and not a real catalog - consists of 287 folia in quarts, listing approximately 5000 works. Our first task was to list all works relevant to Medicine and Natural Philosophy. The full list is presented in the Appendix. Other interests of the Baron, as an Enlightenment ruler were Law, Politics, History, Theology, Literature, Languages/Philology, Geography/Travels. Commerce, Military studies, Numismatics, Economy, Fine Arts and Agriculture.

It is immediately evident the eclectic nature of this collection, including classical works - Hippocrates, Galen, Dioscorides -, some of the latest medical authors of the time - Boerhaave, Friedrich Hoffmann, Haller -, rare books of value to a collector, monographs by unknown authors, among Renaissance and early Modern science canonical works. From the catalog alone, it is impossible to establish what could have interested Hahnemann.

However, an important hint was supplied by $R$. Tischner [11]. upon finding a letter addressed by Hahnemann to an unnamed editor, dated April 12 $2^{\text {th }}$, 1779 asking to publish his German translation of Mirabaud's Système de la Nature.

Mirabaud was a pseudonym used by Paul-Henri Thiry, baron d'Holbach (1723-1789), the most radical materialist and atheist of his time. Système de la Nature was published in 1770 in London (but actually in Amsterdam), to avoid persecution. The possible contribution of Diderot is a subject of debate among scholars $[12,13,14]$.

Fig. 1 Page of numismatic catalog composed by Hahnemann. 


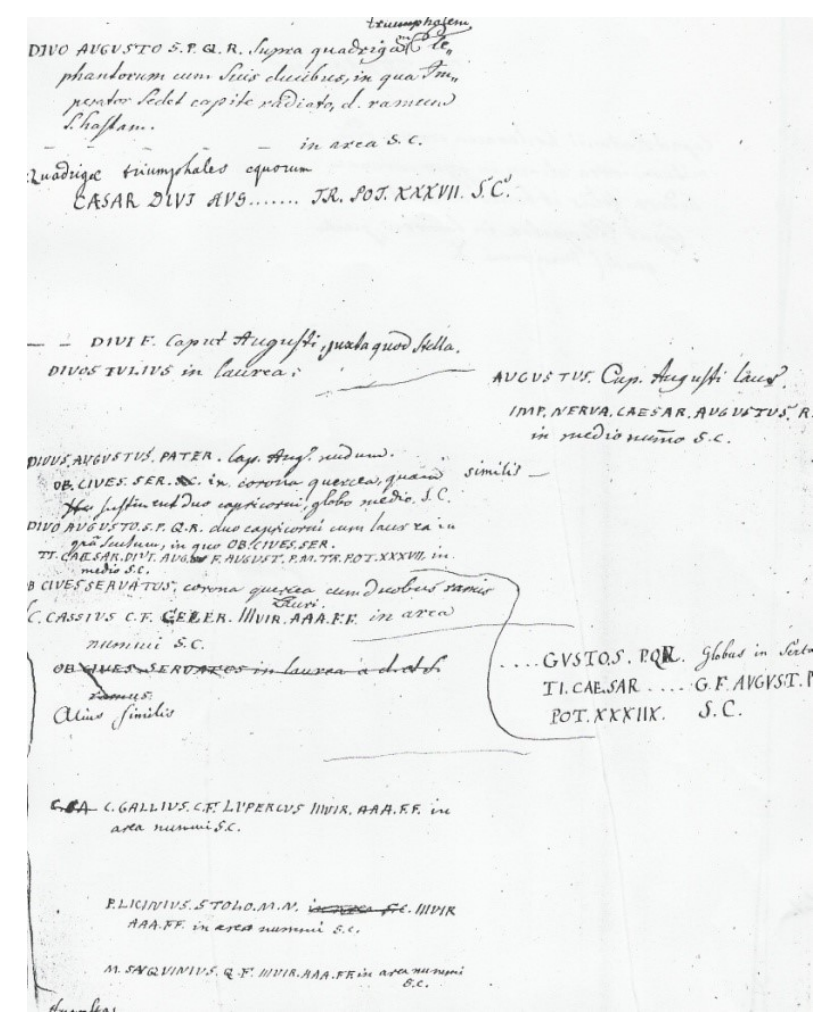

Fig.2 A page of the Catalog, showing Hahnemann's revision. Hahnemann's handwriting can be seen in the lines mentioning Alting, Ampelius, etc.

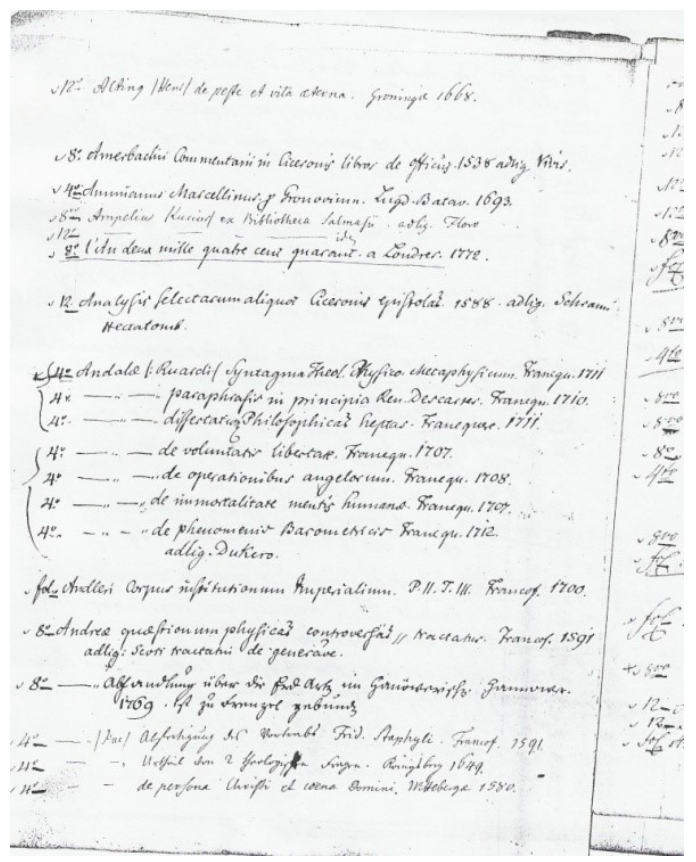

Fig.3 Cover page of Latin translation of the Zohar, Kabbalistic work, stating it was translated from Hebrew and "Chaldaic".

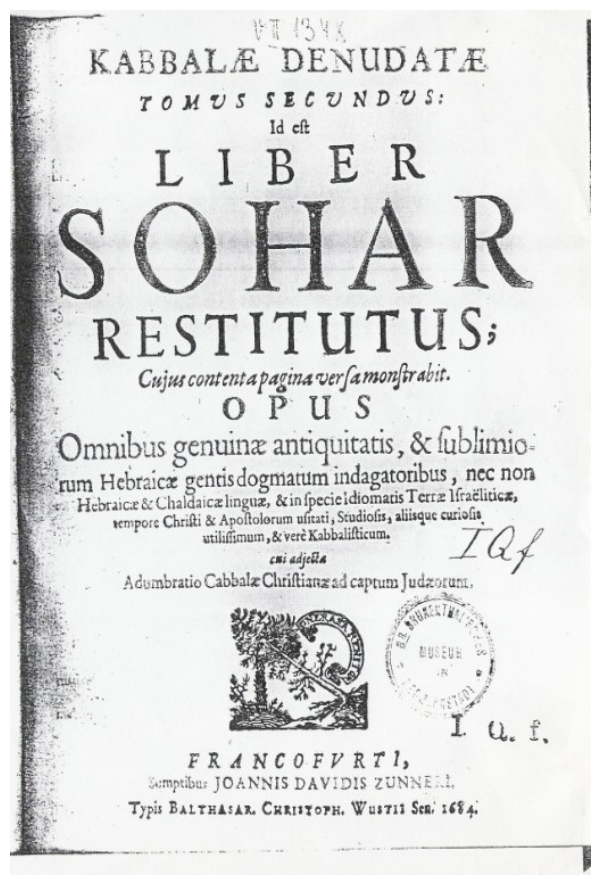

The date of Hahnemann's letter suggests that this translation was made during his stay in Sibiu. Moreover, the original is a large work, two volumes of approximately 400 pages each one; a hand-made translation with feather quill pen under candle-light must have consumed a significant amount of time, which was available to Hahnemann in Sibiu. 
Finally, the oral tradition at Brukenthal Museum merely hinted at by Ordeanu, as mentioned above has that Hahnemann had to leave Sibiu due to an episode involving "a book or a coin", implying a disappearance. Our study allows to suggest that it is highly probable that the motive was indeed "a book", but not due to its disappearance - although at some moment impossible to establish, it actually vanished from the Library-, but to the interest of Hahnemann on it to the point of making a translation and pushing for its diffusion. A book that probably offended the Baron of Brukenthal's religious sensitiveness.

As it must be reminded, the publication of Système de la Nature provoked immediate intense reaction, including the condemnation by the Paris Parliament to be publicly burned by the official executioner, and many refutations, including Voltaire's [12].

It might surprise this interest of young Hahnemann in the most radical materialistic and atheistic work written in the $18^{\text {th }}$ century. Yet, it is explainable. Until that moment, Hahnemann had moved exclusively within highly pious and conservative milieus, from Meissen to Leipzig to Vienna to Sibiu. It is highly improbable that he might have had previous occasions to enter into contact with views radically opposing the established ones. To a young and inquisitive mind, Holbach's formulation might have seemed challenging and perhaps pointing to a sound path for the development of science.

Holbach was no strident author but a highly learned product of Enlightenment, his Paris salon was one of the centers for discussion of the latest trends in science. Besides contributing with many articles to the Encyclopédie, he was the translator of chemical works of Georg E. Stahl into French [15]. His influence helped to draw the map of $18^{\text {th }}$ century - and even $19^{\text {th }}$ century - science.

In Système de la Nature, Holbach, indeed, proposes a daring interpretation of nature as a whole, grounded on the notions of matter and motion, soundly articulated on current ideas concerning Newtonian conceptions and natural laws. In this framework, the human being - in its double "physique" and "morale" aspect - was to be considered a strict product of nature; thus, the study of the human being ought to follow the path of the physical sciences and the path of direct, sensemediated experience [16].

Accordingly, he would conclude that no kind of supernatural agencies needed to be invoked - from gods to sui generis forces - to explain any aspect of the workings of nature. It is evident that the mature Hahnemann would not partake of this position, but nothing can be established concerning his first years, especially those devoted to chemical studies, which suggest an actual interest in the sciences of matter.
Consistent with his ontological grounds, Holbach develops a methodology of study built around the notion of immediate experience of nature. Here his notions and even his tone are immediately evocative of Hahnemann's own:

Men will always be wrong when they abandon experience to follow systems created by imagination. Let man stop searching away from the world he inhabits (...) let him study this nature, learn its laws, contemplate its energy and the immutable way how it works;(...) let him accept to ignore the causes enveloped by impenetrable veils(...) Nature acts through simple, uniform, invariable laws that experience itself leads us to know. It is through our senses that we are linked to universal nature, it is through our senses that we can make it a subject of experience and reveal its secrets; the moment we leave experience, we fall in the void, where our imagination takes us. Men are never wrong when they follow nature, when they abide by its rules, when they call experience to assist them. It is thus that the lack of experience leads to imperfect ideas... delusions. They had ignored nature, ignored its laws... all their systems, their conjectures, reasoning, where experience had been banished, were nothing but a long tissue of mistakes and absurd.

It is only to this rejection of experience that Medicine owes its lack of progress. Scientists had preferred the

... delirium of their imagination and their groundless conjectures to the toil of experience, the only one able to extract from nature its secrets. By lameness or by fear, men have renounced to the evidence supplied by their senses, had only been guided in all their actions and enterprises by imagination, enthusiasm, habit, preconception and especially, by authorities, who knew how to make profit of their ignorance to delude them. Imaginary systems took the place of experience, reflection and reason.

Hahnemann's conception of scientific methodology, including the possibilities and limits of experience would be developed in the course of time and would include other sources. Nevertheless, it is highly possible that this early interest on Holbach contributed to shape his epistemological views. In any case, it cannot be contested that he assumed for himself Holbach's challenge:

Let us free ourselves from an imagination without rules, let us take experience as our guide; let us consult nature; let us extract from it true ideas concerning the objects it contains; let us go back to our senses, which we have falsely considered suspicious; let us interrogate reason, which we have shamefully calumniated and degraded; let us contemplate attentively the visible world and let us see if it is not enough for us to make inferences concerning the unknown lands of the intellectual 
world; perhaps we will find out that there is no reason to distinguish between them and that there is no reason to separate in two empires what equally belongs to the realm of nature.

\section{Acknowledgments}

The authors express their grateful thanks to Dr. Constantin Ittu, Head of Department, Brukenthal Library, Sibiu, Romania and Prof. Dr. Ana M. Alfonso - Goldfarb, Chair, Centre Simão Mathias for Studies in the History of Science, Pontifical Catholic University of São Paulo, São Paulo, Brazil for their assistance.

\section{Bibliography}

[1] Bradford TL. The life and letters of Dr. Samuel Hahnemann. Philadelphia: Boericke \& Tafel; 1895.

[2] Haehl R. Samuel Hahnemann: his life and letters [reprint]. New Delhi: B Jain; 1992.

[3] Tischner R. Geschichte der Homöopathie. Lepizig: Wilmar Schwabe; 1932-1934.

[4] Ordeanu M. Samuel Hahnemann. Sieben Vierteljahre in Hermannstadt [Preprint 2005]. 1777-1779.

[5] Broman TH. The transformation of German academic medicine, 1750-1820. Cambridge: Cambridge University Press; 1996.

[6] Waisse Priven S. Hahnemann: um médico de seu tempo. Articulação da doutrina homeopática como possibilidade da medicina do século XVIII. São Paulo: Educ/Fapesp; 2005.

[7] Bibliotecii Muzeului Brukenthal Ms 87. Sibiu: Muzeul National Brukenthal [updated on 2008 Jan; cited 2008 Dec 01] Available from: http://www.brukenthalmuseum.ro/.

[8] Ruiz R. A montagem da teoria da dinamização dos medicamentos homeopáticos de Samuel Hahnemann [Thesis (Doctorate)]. São Paulo: PUCSP; 1999.

[9] Jurj Gh. Hahnemann at Hermannstadt: discoveries in Brukenthal Library. Sillimum. 2006; 19: 14-43

[10] Jurj Gh. Primeiras influências de Hahnemann: estudo preliminar do Ms 87, Biblioteca de Brukenthal. Cultura Homeopática. 2006; 14: 24-29.

[11] Tischner R. Hahnemann in Hermannstadt. Allg Hom Ztg. 1958; 7: 349-354.

[12] Topazio VW. Diderot's supposed contribution to d'Holbach's works. PMLA. 1954; 69(1): 173-188.

[13] Cushing MP. Baron D'Holbach: a study of eighteenth century radicalism in France. New York: Press of The New Era Printing Company; 1914.

[14] Lange FA. The history of materialism. $3^{\text {rd }}$ ed. London: Kegan Paul, Trench, Trubner \& Co; 1925.

[15] Stahl GE. Traité du Soufre. Paris: Didot; 1766

[16] Mirabaud M, [baron d'Holbach]. Système de la nature ou des loix du monde physique et du monde moral. Leipsick: [s.n.]; 1771.

\section{APPENDIX: WORKS ON MEDICINE AND NATURAL PHILOSOPHY IN BMB MS 87 [ ] Illegible}

AELIANI. De natura animalium LL XVIII graece et lat cur gronov Tomi II vol I. Londini, 1744.

AESCLEPIADEI. Liber de conservatione sanitatis. Neustadeii, 1747.

AGRICOLA, Georgi. De re metallica Libri XII. Basileae, 1657.

AGRIPPA, Henr. Corn., ab Nettesheim. Opera. Tom I-II. Lugd.Batav., 1667.

De incertitudine et vanitate scientia. Francofurt, 1522.

De incertitudine et vanitate scientiarum declamatio Stem Joh. Indaginis. Introductio in Astrol [].

De occulta Philosophia Libri III. 1533.

ALBERTI MAGNI. De secreti mulierum adlig Aristotelis problematibus.
ALBERTO. Avium. Königsberg, 1646.

ALEXANDRI, Joh. Synopsis algebraica opus posthumum. Londini, 1693.

ALIDII, Car. Ant. Somnia medica. 1720.

ANDREAE. Questionum physicae controversiae tractatus. Francof. 1591 adlig Scoti tractatus de generatione.

AMMIANUS, Marcellinus. Rerum gestarum Libri XVII cum observationibus Valesii Lindenbroch. Paris, 1681.

BARBENIUS. De hemorhoidibus vesicae urinariae dissertatio. 1777.

BARTHOLINI, Casp. Astrologia. 1624.

Basilicon sinensis.

BASSI, Cassiani. De re mistica libri XX graece et latine. Cantabrigiae, 1704. 
BASSIANI. Iatrologia adlig Cornar. Basileae, 1543.

BASSINELLER, Gebh. Chr. De medico ex volutati aegroti perpera curante. Vittleberg, 1719.

BAUHINI, Joh. Historia plantarum universalis T III. Ebroduni, 1650.

BAYERI. Lux mentium universalis [ ] 1663.

Avium naturae. 1662.

BAYLE, Franc. Institutiones physicae. T. III. Francof., 1703.

BECKERES, Heinr. Microscopium [ ] 1756.

[ ] der Microscopii. Augsburg, 1754.

BERKERI, Dan. Historia morbi academici. Regiomonti, 1649.

BERNHARDI, Gregorii. Florilegium illustrium a selectorum questionum. Lipsiae 1619.

BERNOUILLI, Joh. Opera omnia Tom IV. Lausannae 1742.

BERTRUTII. Methodi cognoscend[ ] morborum. Magunt., 1534 adlig Haylii artig. medica[ ].

BEYERI, Georg. De structura hepatis diss. Regiomonti, 1650.

BEYERI, Har[]. Quaestiones in libr de Sphaera Joh de Sacrobst. Francofurti 1560.

BIDLOO. Exercitationes anatomico chyrurgicae P I et II. Lugd Batav., 1708.

Anatomia. Amstelodami, 1685.

BOERHAAVE. Methodus studii medici Tom II [ ] 1751 cum Indice. Lugd. Bat., 1759.

1733.

Epistola anatomica de glandulis. Amstel.,

Prelectiones academicae [ ] Halleri T IV. Gottingae, 1740-1743.

Historia plantae in horto academic[ ] Lugd. Bat. [] Londini 1731.

BOETII, Anselmi. Gemmae et lapidum historia recenjuct et Mustravit Adrianus Tollius. Lgd.Batav., 1647.

BOHNII, Joh. Casus aegri somnambulantis, 1717, adlig Schenchzer.

BONANII, Ph. Historia Rerum naturalium in Musei Kircheriano existentium. Romae, 1773.

BORELLI, Joh. Alph. De vi percussionis. Lugd.Batav., 1686.

De motionibus naturalibus agravitate pendente. Lugd.Batav., 1686.

BORN, Ignaz. [] über Mineralogie [ ]. Leipzig, 1774.
BOYLE, Robert. Experimenta, observationes, etc. Londini, 1692.

1661.

[ ] experimenta physico-mecanica. Haya,

Paradoxa hydrostatica. Rotterdami, 1670.

Opera variorum medicibus mubisque figuris [ ] vol. III. Geneva, 1680.

Eadem Opera. Vol. 1. Geneva, 1680.

BRADLEY. Dictionarum Botanicum. II Vol. London, 1728.

BRISSON. Ornithologica latina etgall cum fig. Parisus, 17[].

BROUNE. Religio medica cum annotationibus. Argentorum, 16[].

BRUNNERI, Erh. De febri epodemia diss. Duisburg, 1700 .

BRUYERE de la. Characteres de Teophraste. T. II. Paris, 1750.

De BRUYN. De natura et proprietate lucis. Amstelod., 1663. adlig Gilbert philosoph.

BUFFON. Histoire naturelle en XV volumes. Paris, 1749 .

CARL, Joh. Sam. Otia medica ist bey Comenius gebund. 1720 .

CAROPHILI, Blasii. De antiquis marmoribus opuscularum. [ ], 1743.

CARYOPHILI, Blasii. De veterum elypcis opusculatum. Ludg Batav 1751.

De antiquis metalli fodinis. Viennae, 1757.

CASMANII, Oth. Psychologia antropologica. Hannoviae, 1594.

Idem partes II. Hanoviae, 1594-1596.

Somathologia phusica grlis. Francf., 1599.

Angelographia. Francoforti, 1597.

CASSEBOHM, Joh. Frid. Tractatus V anatomici de aure humana, tribus figurarum tabulis illustratia. Halae, 1734.

CELLARI, Andr. Harmonia macrocosmica seu Atlas universal totius universi creati. Amstelod., 1708.

CELSI, Aur. Cornel. De re medica libri VIII. Lugdun., 1587.

De medicina. Lugdun., 1675.

De medicina libri VIII. Lugd. Batavor., 1730; Amstelod., 1713.

CHENOT, Adami. Tractatus de peste. Vindobonae 1766. 
CIASSO. Meditationes de natura plantae. Venetiis, 1677.

CLERICI, Joh. Physica. Amstelod., 1696.

Compendium historiae universalis. 1698.

CLEOMEDES. De Mundo. Basileae 1565.

COBABI, [ ]. Brevis astronomiae delineatio. Rostochii 1643.

CORNANI, Jani. Universae rei medicae epigraphe. Basileae, 1534.

CRAANEN, Theod. Tractatus physico medicus de hominis. Lugd. Batav., 1689.

CRASSO. Meditationes de natura plantarum. Venetiis, 1677 adlig. Jons[] Taumatographicae.

CRUSII, David. Theatrum morborum Hermetico hypocraticum. Erfurti, 1616.

CUDVORTHI, Rudolphi. Sistema intellectuale hajus Universi. T. I-II. Jenae, 1733.

. Systema. London, 1678.

CUMERLAND. Traité philosophique des loix naturelles. Amsterdam, 1744.

Dictionarum medicum. exud. Henr. Stephanus, 1564.

DIMIEN. De generatione augmentatione microcosmi. Lugd. Batav., 1689.

DIONYSII. Geographia p Edw Wells. Oxonii, 1704.

Afri descriptio orbis adlig Proclo.

Areopagitae. Opera omnia unni paraphrasis. Lutetiae Paris, 1615.

Descriptio orbis adlig Ruffu. Viennae, 1515.

DIOSCORIDIS ANAZERBEI, Pedani. De medicinali materia libri sex. Johanne Ruellio interprete. Lugduni, 1552.

Disputatio medico historica de variolii. Ratisbonae, 1763.

[ ] Dissertatio de Igne. Viennae 1773.

De ELIACO, Petri. Tractatus s super libros meteor. Viennae 1514 adlig Rufo.

ERNATELIS, Chris. Henr. [ ] physiae illustrata. Dresde, 1736.

EULER, Leonh. Intro. in Anal. infinitor. Lausanne, 1748.

Scientiae [ ]. Petropoli, 1749.

FERRETII, Joh. Bapt. Musae lapidariae antiquorum. Verona, 1672.

FLUDD, Rob. Philosophia Mosaica.

FONTENELLE. Oeuvres diverses. Paris, 1715.
FORSTER, Georgii. Characteres generum plantarum. Londini, 1776.

FRIDVALDSKI, Joh. Minerologia [ ]. Franniae [ ] 1767.

FROMII, Mar. Gotlieb. De differentia graduali morbor[] maligno[]. Erfordiae, 1465.

FUCKER, Frid. Jean. Dissertat. Medica. Tyrnarviae, 1773.

FUMANELLI, Ant. Tractatus medici/aliquot Comari/ Basileae ex off Joh. Opposini, 1543.

GAILL, Andr. Practicar observationarum libri II. Colon Agrip 1625.

GALENI, Claudi. Methodis medendi latine. Lugd., 1553.

De morbos causis et differentia. Ibid, 1560.

De alimentorum facultatibus. Ibid, 1570.

De sanitate tuenda. Ibid, 1549.

De crisibus. Ibid, 1558.

$\frac{}{1551 .}$ De anatomicis administrationibus. Ibid, De locorum affectorum notitia. Ibid, 1562. De offibus. Ibid, 1551.

Ars medicinalis. Venetiis, 1627.

GILBERTI, Vil. De mundo nosso sublunari nova Philosophia. Amst., 1651.

GIORII, Petri. Arcanum acidularum. Amstel., 1682.

GORLAEI. Dactyliotheca P I et II explicationibus Gronovii. Lugd Bat 1707.

GRAVESAND. Phil. Newt. Institutiones. Leid. \& Amst., 1728.

GUERICKE, Ottonide. Experimenta nova de vacuo spatio. Ams. 1672.

De HAEN. De magia liber. Leipzig, 1774.

HALLER, Albrecht. Anfangt gründen In. Phisiologie [] ihm latninische übersetzung [ Joh Sam Haller vol VI. Berlin, 1759.

Londini et Leipzig, 1775-76.

Usong. Bern, 1771.

[] Bern, 1773.

HAMEL. De mente humana. Paris, 1677.

HAWKSBEE. Experiences physico-mech. Paris, 1754 .

HELLII, Christoph. Paraphrases in Galleni Librum De Arte Med. 1534.

HELMONT. Alfabeti reu naturalis. 
HELSHAMI. Physica experimentalis. Vindobonae, 1769.

HENTSCHEL, Gottl. Dissertatio de siri lactis virtute longe saluberrima. Halae, 1725 ist bey Comen. gebunden.

HESSI, Eobani. De tuenda valetudine libellus. Francof adlig Scholae salernitanae.

HEYL, Christopher. Artificialis medicatio seu paragraphi in Galenum De artis medicae [] 1534.

HIPPOCRATIS. De insomnium liber. Basileae ex off Por, 1549. adlig Cornasio.

Aphorismi eius veroi lectio. Ibidem.

Libelli aliquot preparatorii ad artem medicam, item Cornani Hippocratei sive Doctor verus. Basileae ex off Opor 1549 adlig Cornasio.

Opera graece per Trobenium. Basileae 1538.

1665.

Opera omnia graece et latine. Lugd. Bat.,

Opera omnia graece et latine curante. Stephane, Mackio Tomi II. Viennae, 1743 et 1749.

XXII Comentarii tabulis illustrati graece et lat. [] Jani Cornaris [] Zuinger. Basileae, 1579.

HOFFMANN, Frid. De hepatis inflammatione. Halae, 1721 adlig. Schenchzen.

Schenchz.

De medicina emetica. Halae, 1721, adl. Chark.

De Bom pour nickel. Halae, 1695 adl. a

De balneorum usu in affectibus interniv. Hale, 172[ ] adlig. Schenchzer.

De curatione calenti. Halae adlig. Schench.

De modo historias morborum recte consignand. Halae adlig Schenchzen.

HOFFMANN, Bemb. Ner. De util practico remedii servi corrupti. 1735.

HOLLER. Jac. de materia chyrurgica. Paris, 1567.

HOLLERI, Jacobi. De morborum internor curatione. Paris, 1567.

HUGOTTI, Steph. De corporibus [ ] principiis et affectio. 1695 .

De prudenti medicamentorum applicatione. Halae, 1695.

HUMBURG, Joh.Nep. Dissertat. de hemorhoidibus. Vindobonae, 1765.

Epist. Resp ad [ ] de civium [ ] epidemia. Vindobonae, 1771.

KASCHNENIG, Joh. Baptista. Regni mineralis pars nobilica. Viena, 1752.
KUNSTEL, Volfg. Diss. De salibur metallor. Lipsiae, 1711.

LAET. De gemmis et lapidibus. Lugd. Batav., 1647.

LAEVINIUS Lemnius. The secret miracles of nature. London, 1658.

LANATHERI, Joh Henr. Dissertat de Ictero. Erfordiae 1721 v Schenchz.

LANGII. Dissertatio de ophtalmia. Tyrnaviae, 1777.

LASSONE, Mr. de. Rapport des Inoculations. Paris, 1774 .

LAVATER. Physiognom [ ] IV []

LEADBETTER, Charl. The young mathematician. London, 1748.

LEEUVEN, Henr. De corporis essentia. Lugd. Batav., 1694 ad a Chark.

LEEUWENHOEK, Antonii. Anatomia seu interiora verum. Lugd. Batav., 1687.

Arcana naturae derecta.

Continuatio Arcana naturae detecta. Delphis, 1695-1697.

Epistola Physiologicae. Delphis, 1719.

Opera vol. I II tomis quator. Lugd. Bat. Ab 1719-1722. Quorum $1^{\circ}$ continet Anatomiam; $2^{\circ}$ Arcana naturae et continuationem epistol.; 3 . Continuationem Arcanorum; 4. Epistolas ad Soc. Reg. Angl. et alios.

LEMMII Lovini. Natura miracula occulta. 1588.

LICETI, F. Hierogliphica sive antigua schemata gemmarum annularium. Patavii, 1653.

Van LOON, Gérard. Hist. Metallique de XVII Prov. de Pais. Bas., 1732-1737.

MAJORIS, Dan. Historia calculorum in renibus Sperling repertor[]. Lipsiae, 1662.

MAYOV. Tractatus duo, prior de respiratione, alter de raihitide cum fig [] Lugd Batav, 1671.

MEAD, Rich. Mechanica expositio venenorum, accedit ejusdem de imperio solis ai luna in corpora humana. Lugd.Bat., 1737.

Oratio aniversaria Harveiana 1728.

Medical essais and observations revised and publiched by a Society in Edinburgh. 4 vols. Edinburgh, 1737-38.

MIRABEAUD. Systeme de la nature. Tom I-II. Londres, 1770.

[] Diss. H. De origine animae rationalis. Regiom., 1650 .

NEUSTAEDTER, Mich. [ ] casuum medico chyrurgico. Erlangae, 1762. 
NEUTON. Philosophiae naturalis principia mathemarica. Amstelod., 1714.

Onomatologia botanica. [] 1-9. Leipzig, 1722-77.

PITCARNII, Archibaldi. Opuscula medica. Ed. $3^{\mathrm{a}}$. Roterod., 1714. adlig Curiosit. Philosoph.

PRESLE, Le Regne. Medicinisch historisch [ ] Nürnberg 1766.

PREUSSII, Georg. Diss. de Magica transmutatione in bruta. Regiom., 1650.

PREVOTIUS, Joh. Mendicaments for the poor. London, 1617.

PRISCIANI, Theod. Phaenomenon eph[ ]osiston. Basileae ex off Trobeniana, 1532 adlig Cornar.

et Marsilii in Theophrasteu de sensu plantas et intellectu explica[ ] adlig Iamblichio.

RIVETI, Andr. Epistola de peste ad amicum. Lugd Batav 1655.

ROBERGI, Laur. Positiones medicae. Lugd. Batav., 1693.

ROBINSONIS, Hugo. Annalium mundi universalium, origines rerum et progressus ab orbe condito tradentium tomus unicus. Londini, 1677.

Scholae Salernitana Opuscula de conservanda valetud[ ]. Francof.

SCHARF. Pneumatica. Vitterbergiae, 1629.

Joh. Metaphysica exemplaris. Vitterbergiae, 1694. A Pneumatica- Ibid, 1629.

SCHMID, Joh. Christ. Dissertat. De mixtione corporis humani. Jenae, 1765.

SCHROEDERI, Joh. Pharmacopoeia med. chym. Ulm, 1650.

SENNERT. Epitome.

SPAN. Speculum iuris metallici. Dresden, 1698.

ST. ANDRÉ [ ] sujet de la magie a Paris 1725.

STEPHANI, Henrici. Dictionarium medicum.

STIERI, Joh. Precepta Physicae, 1639.

Precepta Ethicae, 1651.

Precepta Logicae, 1649.

Doctrina Sphorica, 1652.

Van SWIETEN. (Comm. Boerhaave)

STRUVII, Joh. Adam. Diss. medica de spedris. [ ] 1725 .

THEOGNIDIS Gnomonologia.

Phocylidis, Pythagorae, Solonis et alior poemata gnomonica opera Tridenci Sylburgi Ultrajecti 1659.
TEUTSCH. Dissert. de tinctura Martial. Traj ad Rhen, 1693.

THEOPHRASTI. Historia plantarum Libri IX. []

Thesaurus gemarum. []

TRIGLADNI. Disput. De generatione, augment et decretione microcosmi. Lugd. Bat., 1689.

TOURNEFORT, Joh. Pitton. Institutiones rei herbaria. T II P III. Parisiis, 1703.

Traité de la matiere medicale. A Paris, 1717.

[ ]. Nürnberg, 1776.

VAGNES, Lucae. Dissertatio de agnis medicalis Transilvaniae. Vienae, 1773.

VASIENSIS, Mich. Dissertat. de metallo regio. Lugd. Bat., 1685. adlig Kumstel.

VATER, Christ. De convulsivis morbis. Vittebergiae, 1708. \} adlig

De pulsis agrus vitae et morbis. Vittebergiae, 1708. Schenchz.

Schenchz.

De venenis et philtris. Vittebergiae, 1708. Schenchz.

De visionis laesionibus. Vittebergiae, 1708.

De trachomata. Vittebergiae, 1708. quer. Schenchz. Schenchz.

De ulceribus vesicae. Vittebergiae, 1708.

De uteri morbis. Vittebergiae, 1708. Pisciuum. Schenchz.

Abrah., De mechanismo action[ ] vitali[ ]. Vittebergiae, 1708. Schenchz.

De eo quod $\quad \square \square \square \square$ habez in rebus naturalibus. Vitterbergiae, 1707.

De musculo orbiculari [ ]. Amsterdam, 1727.

VENITTE, Nicol. Traité des pierres que s'engendrent dans les terres et dans les animaux avec figures. 1701.

WHYTT. Works. 1768.

WILHELM, Nic. Diss. de salivat mercurialis. Lugd Bat, 1694.

WILKINS. Mercury or the secret and swift messenger. London, 1694.

ZWINGER, Th. Theatrum vitae humanae. Vol. XXIX. Basil., 1586.

1697.

Scrutinium Magnetis medico psych. Basil.,

[] Mathematisch[]

[ ] Allgemein Natur[] VII [] Londini, 1771-74. 
[ ] Positiones de peste. Claudiop. 1720.

\section{(cc) EY-NC-ND Licensed to GIRI}

Support: authors declare that this study received no funding

Conflict of interest: authors declare there is no conflict of interest

Received: 05 December 2007; Revised 12 April 2008; Published: 30 June 2008

Erratum: 30 Dec 2008. (http://www.feg.unesp.br/ 0js/zacha ijhdr/erratum/?v=7\&i=23\&pi=93)

Correspondence author: Silvia Waisse Priven; silvia.priven@gmail.com

How to cite this article: Waisse Priven S, Jurj G. Hahnemann in Sibiu: possible influence of the ideas of Baron d'Holbach. Int J High Dilution Res [online]. 2008 [cited YYYY Mmm DD]; 7(23): 93-102. Available from: http://www.feg.unesp.br/ ojs/index.php/ijhdr/article/view/53/344. 